\title{
A Commentary on Adam Smith and International Business
}

Mats Forsgren and Mo Yamin

\begin{abstract}
A close reading of Adam Smith's works, "An Inquiry into the Nature and Causes of Wealth of Nations" and "The Theory of Moral Sentiments," indicates that he would not support the advocacy of free markets wholeheartedly. His view on market systems, although "free," implies strong institutions and regulations. Adam Smith would have been particularly concerned with the fact that the large multinationals are as much political actors as they are economic actors. He would have argued that there may be 'moral' limits to globalization. In his view, the general rules of morality are (in modern parlance) 'socially embedded.' Thus, sympathy and fellow-feeling mostly operate at 'close quarters' and, in particular, they may not be effective at a transnational level.
\end{abstract}

\section{INTRODUCTION}

In this paper, we reflect on our reading of Adam Smith's most important publications: "An Inquiry into the Nature and Causes of Wealth of Nations" (1776) and "The Theory of Moral Sentiments" (1759), from a broadly international business perspective. We organize our reflections around the following quasi-rhetorical question: If Smith were alive today, would he belong to the Adam Smith Institute (the leading pro-market 'think-tank')? Although now famed for his advocacy of the market and the so-called 'invisible' hand, our reading and interpretation of his original works suggest that Smith would not necessarily wholeheartedly support the advocacy of free markets enthusiastically undertaken by the Adam Smith Institute: he would share many concerns with writers who view the 'retreat' of the

\footnotetext{
Mats Forsgren is professor emeritus in International Business at The Department of Business Studies, Uppsala University. His publication includes over 50 articles and books concerning foreign direct investment theory, the internationalization process, managing the multinational firm and business network theory. His latest book is Theories of the Multinational Firm (2008 Edward Elgar). E-mail: mats.forsgren@fek.uu.se
}

Mo Yamin is a Reader in International Business at the Manchester Business School, The University of Manchester. His recent research has been on subsidiaries within multinational companies, small firm internationalization and the role of the internet in the internationalization of firms. He has published papers on the enduring relevance of Stephen Hymer's contribution to understanding key issues within international business. E-mail: mo.yamin@manchester.ac.uk 
state with apprehension (Strange 1996) and with those who consider that globalization may have gone 'too far' (Rodrik 1997). With respect to the 'invisible hand,' a reasonable interpretation is that the market system requires strong institutions and strong regulation: individuals pursue their interests within the rules of well-defined games in which attempts by the powerful to influence the institutions are not allowed. With respect to the multinational enterprise, our interpretation is that Adam Smith would have been particularly concerned with the fact that the large multinationals are as much political actors as economic ones and that they may exert more political power than representative and (at least partially) accountable institutions, such as governments.

Focusing on "The Theory of Moral Sentiments," our interpretation is that Smith would have argued that there may be 'moral' limits to globalization. In the book, Smith develops a theory of individual moral responsibility. Although individuals are fundamentally disposed to 'sympathy' and 'fellow-feeling,' the general rules of morality are (in modern parlance) 'socially embedded.' Thus, sympathy and fellow-feeling mostly operate at 'close quarters' and, in particular, they may not be effective at a global or trans-national level. In turn, this suggests that there are inherent difficulties in developing overarching institutions that commend general legitimacy.

\section{Adam Smith and International Trade Theory}

\section{Adam Smith and International Trade}

In "An Inquiry into the Nature and Causes of Wealth of Nations" from 1776, Adam Smith lays the foundation for the international trade theory that was later formulated and developed by Ricardo, Heckscher-Ohlin, Burenstam-Linder, Vernon, Krugman, and others. The basic message of the book is that countries will prosper from trade with each other because they can exchange advantages and use division of labor. This view is in contrast to what was the dominating mercantilist view at the time that a country must maximize its exports and minimize its imports as much as possible in order to maximize the country's gold reserves. Smith shows that trade is beneficial for both countries in terms of productivity and growth; therefore, "An Inquiry into the Nature and Causes of Wealth of Nations" is a plea for a non-protectionist policy. It is also said to be a plea for liberalism, in which the market plays a central role and the state a limited role. The philosophical background is individualism and utilitarianism. 
Does this mean that we would expect that Adam Smith would have also been positive to the globalization of today in terms of international trade? Not necessarily. Adam Smith's world consisted of small entrepreneurs that used the free market to sell and buy products. To the extent such selling and buying included customers and suppliers in other countries, trade had become international. The main argument was that the benefits of division of labor through specialization do not stop at country borders. The same logic is applied on the country level as on the firm level. Consequently, we would argue that to the extent division of labor is carried out by and between numerous, independent firms (none with monopolistic power of any kind), it is in line with Adam Smith's assertion of the wealth creating impact from international trade. But if we consider that 1) at least one-third of international trade is intra-corporate trade and 2) that some global markets are dominated by few players with considerable market power, the so-called "free market," like the one Adam Smith was analyzing, is only a part of what today we call international trade. Or expressed differently, Adam Smith's basic assumption that no business actor is, or should be, large enough to "control" a larger part of the market activities than his own activities, is probably severely violated today. International trade in "An Inquiry into the Nature and Causes of Wealth of Nations" is quite different from international trade today, and Smith's view of the benefits of international trade, therefore, must be applied with caution.

\section{The Invisible Hand}

Adam Smith's view on international trade is closely linked to his use of the term "the invisible hand." In"An Inquiry into the Nature and Causes of Wealth of Nations," he uses this expression only once(!), but the concept has had a profound impact on later interpretations of Adam Smith's work - and on international trade theory in general - especially during the 20th century. He uses the invisible hand metaphor in arguing against restrictions on imports. His major concern is merchants holding monopolies of different kinds, partly due to different kinds of import restrictions. According to Adam Smith, these merchants formed an"overgrown standing army, who "upon many occasions intimidate the legislature"(Rothschild 1994, p. 319). If import restrictions are eliminated, the merchant will still prefer to support the domestic industry to that of foreign industry, "in the interest only of his own security; and by directing that industry in such a manner as its produce may be of the greatest value, he intends only his own gain; and he is in this, as in many other cases, led by an invisible hand to promote an end which is no part of his intention" (Smith 1976, p. 260). 
The common interpretation of the invisible hand metaphor in relation to international trade theory is that the fewer the legal and social restrictions on firm behavior, the better for society as a whole. In that sense, the invisible hand suggests a first-order social system under which everything else must be subordinated. Therefore, it fits well with a dominating philosophy of international trade theory - as well as with the market liberalism doctrine _that, in principle, there should be no restrictions (nor any particular encouragement) whatsoever when it comes to trade or capital movements within or between countries.

But what is Adam Smith's own interpretation of the invisible hand? He is obviously a great defender of individual freedom. But does that mean he also thought of the invisible hand as a first-order social system? It has been argued that the use of the term invisible hand by Adam Smith is more ironic than anything else. At the time when "An Inquiry into the Nature and Causes of Wealth of Nations" was written, the term 'invisible hand' was mostly used in connection to critiques of established religions in which the "invisible" is a "Divine Being." Examples of divine beings were"fairies, Nymphs, Fawns, Satyrs, and Dryads" (Rothschild, 1994).

There are certain indications that Adam Smith used the term differently from how it has been interpreted by 20th century economists. First, his view of agents in the system is quite condescending. Their intentions are puny and futile. They are blind in the sense that they cannot see the hand by which they are led. They have no ability to understand the system under which they live, just their own local circumstances and narrow personal interests. This stands in contrast to Adam Smith's writings elsewhere in which he recognizes that human beings have the possibility to see to interests beyond their own undertakings. It is a reasonable hypothesis that the term invisible hand is used more in relation to his caricature of merchants being narrow-minded defenders of trade restrictions and subsidies rather than as a strong plea for the only reasonable social and economic system.

Second, it is interesting to observe that the invisible hand implicitly assumes that at least one agent, a theorist or a legislator, must have the ability to design and control the whole system. Somebody must have a visible hand in order to be able to design a system in which all the other agents are "blind." This assumption implies that one claim made for the invisible hand is to suggest ways to devise institutions and policies that harness self-interest for the social good. Its effect is to leave agents open to manipulation by authority. This assumption is in a sense quite un-Smithian and is a further indication that Adam Smith used the term rather as an ironic but useful joke. It has also been pointed out that at the time the 
book was written, the notion of unintended consequences was often used as a cliché against freedom of commerce and individual independence (Rothschild 1994, p. 320-321).

Third, Adam Smith's main concern in the chapter in which the term the invisible hand is used is the market and political power of business agents. He identifies a problem connected to the fact that there was a strong tendency among merchants to pursue their own interests by successfully influencing governmental institutions, for instance in order to uphold import restrictions. The invisible hand concept is in fact an important part of Adam Smith's critical analysis of the unhealthy relations between some agents and the government. In Adam Smith's analysis, the function of the invisible hand is highly dependent on whether business agents pursue their own interests by political influence or by "market actions." A reasonable interpretation of Adam Smith's view on the invisible hand in this context, therefore, is that a market system requires strong institutions and strong regulations. It is a system in which individuals pursue their interests within the rules of well-defined games, of which attempts to seek to influence institutions is not a part. In this sense, the invisible hand is paradoxically closely connected to regulations and limitations of individual freedom rather than to deregulation and removal of restrictions on individual freedom. Expressed differently, Adam Smith's main concern is not limitations of the individual freedom in general, but the restrictions imposed on some agents due to the fact that some other agents have power to influence institutions and law-makers. Therefore, the invisible hand cannot be interpreted as the first-order system in Adam Smith's world, but a second-order system contingent on a first-order system of strong institutions and regulations in which no agents have enough power to influence politics in line with their own interests (Sen 2009).

In Adam Smith's thinking, the invisible hand can be seen as a "trinket" rather than a basic building block (Rothschild, 1994). Or to put it otherwise, the importance that has been attached to the invisible hand by later international trade theorists is maybe exaggerated or even misleading. Consequently, we may not be sure of how Adam Smith would have looked upon the globalization of today with its strong deregulation of trade and capital movements, especially with strong business actors on the international scene.

An interesting notion is that Adam Smith assumes that a removal of trade restrictions will not change the merchants' willingness and tendency to support the domestic industry rather than the foreign industry. The idea about the invisible hand seems, first of all, to be part of a counter-argument 
against the common view at the time that import restrictions are needed in order to stimulate producers to put their capital into specific domestic industries. He simply says that they will do so anyway. The producer is rational and will do so for his "own security" and because "he wants to employ his capital as near home as he can" (Smith 1976, p. 259).

It is also interesting to observe that, although he was much in favor of free trade, he thought that it should not be based on nations' self-interest but on sympathy and friendship. He was concerned by the fact that so much international trade had "become the most fertile source of discord and animosity" (Smith 1976, p. 283). In that sense, Adam Smith's concern about international trade contains a warning against the invisible hand rather than a plea for it.

Consequently, it is reasonable to argue that the concept of the invisible hand is used by Adam Smith in the context of a debate about trade protections and not as a general idea about how a society should be designed. It is also interesting to note that Adam Smith was quite trustful when it comes to the merchants' priorities. They will first of all invest their capital in their home country and use their surplus from the home production to buy goods that are better produced abroad. In that sense, their foreign activities are more on the margin, a 'residual phenomenon' that reflects that the domestic demand is less than the volume of output than the domestic industry is able to deliver. He argues that enterprises must be able to sell their products abroad and buy products that are more efficiently produced abroad. It is a question of division of labor across countries. He did not seem to doubt that enterprises first invest all of their capital in the country and the community in which they are located. Appropriately, Adam Smith's theory of international trade has been characterized as a 'vent for surplus' theory (Myint 1971).

\section{Adam Smith and the Multinational Firm}

Mainstream economic theory still looks upon the politics as an exogenous factor, that is, firms adapt to politics, not influence it (Fligstein 2001). Adam Smith probably would not have been comfortable with this assumption. He would rather have viewed political influence exerted by business actors as a serious matter and as a threat to social welfare and economic growth (Koenig and Waters 2002).

Adam Smith's market consisted of small owner-managed enterprises located in the community where the owners reside. His reasoning about the merchants' priorities reflects a view that these enterprises share the 
community's values and have a personal stake in the future of both the community and the enterprise (Korten 2001). Therefore, the intention to maximize the enterprises' own interests is modified by the enterprises' embeddedness in the local community. Or expressed differently, the invisible hand does not rule alone. Other loyalties also exist. In"The Theory of Moral Sentiments" he is fairly explicit on this. Referring to what we may call small- or medium-sized businesses, Adam Smith observes that the success of such businesses depends on the favor and the good opinion of their neighbours and equals.

He was also concerned about the fact that some enterprises became corporations, that is, joint-stock limited-liability companies run by managers. He firmly opposes absentee ownership: “The directors of such companies, however, being the managers of other people's money than of their own, it cannot well be expected that they should watch over it with the same anxious vigilance with which the partners in a private company frequently watch over their own.... negligence and profusion, therefore, must always prevail, more or less in management of the affairs of such a company"(Smith1976,p.423).His attitudealso reflects his risk-averse nature. He criticizes managers who abandon conservative business practises "in consequence of some flattering speculation of extra-ordinary gain" (Koenig and Waters 2002).

He was also concerned about economic integration and power of enterprises. "An Inquiry into the Nature and Causes of Wealth of Nations" contains an extensive plea for a system with as few firm privileges as possible given by the Crown to specific enterprises or industries. He maintains that such privileges simply distort the market's natural ability to establish a price that provides a fair return on land, labor, and capital and to optimally allocate society's resources (Korten 2001).

It is striking that what he seems to dislike most when it comes to the type of enterprises, corresponds quite well to the enterprises that dominate our present globalization. First, multinationals are often said to be relatively "foot-loose." They are not anchored in a specific local community in the way Adam Smith assumed. They are, therefore, much more geocentric than Adam Smith's enterprise. Consequently, they have no special moral commitments to the home country and do not tend to support the domestic industry just because it is domestic.

Secondly, they are run by managers who basically invest other people's money, not their own. This will increase the risk that some international businesses will become just as speculative and short-term oriented as he 
warned against. Finally, some multinationals are far beyond Adam Smith's enterprise in terms of size and power. Although there are approximately 70,000 multinationals, the stock of foreign direct investment is highly concentrated to a few enterprises. The 100 largest non-financial multinationals account for approximately $13 \%$ of all employment of all multinationals in the world. Further, these and other multinationals have built up their international position largely by buying firms in foreign countries. The estimated amount of mergers and acquisitions across borders is on average about two-thirds of the total amount of outflow of foreign direct investment over the last two decades (Forsgren 2008).

To sum up, the enterprises that play such a profound role in today's globalized world are not the enterprises on which Adam Smith built his model of markets and of international trade. This is of course not a very surprising conclusion. After all, the world has changed dramatically since 1776 in terms of technology, political institutions, and business agents. We cannot expect that the empirical base, on which a theory developed more than 200 years ago, would be unchanged. More interesting, though, is to address to what extent his reasoning is still relevant in the present context. In order to do so, we need to speculate. On one hand, Adam Smith would probably have argued that to the extent that international trade of today means exchange of products between a large amount of independent merchants, based on division of labor and different factor endowments, it is as beneficial for economic welfare as it was in 1776. On the other hand, had he learned about Krugman's New Trade Theory, in which the advantage exploited is based more on first mover advantage because of an early entrant into an industry that supports only a few firms due to economies of scale, he may have been more skeptical.

There are two reasons for this. First, New Trade Theory recognizes that international trade is largely a matter of oligopolistic structures with few but powerful actors. Adam Smith's conceptualization of a market and its relation to economic welfare is closely linked to the idea of many actors in which no one has power enough to dictate conditions for other actors. He dislikes most forms of monopoly in business life. Second, New Trade Theory also implies that there is room for government intervention and strategic trade policy. To some extent, comparative advantages can be "created" by governments through sophisticated and judicious use of subsidies. According to the theory, such policies can increase the chances of domestic firms becoming first movers in newly emerging industries. Adam Smith was very critical of the Crown awards of monopolies to chartered corporations, such as the English East India Company. He argued that such a policy ruined the market system (Koenig and Waters 2002). 
He was also very skeptical when it came to the government's actual ability to evaluate what industry to support and its ability to make better decisions than the myriad of decisions made by all the merchants in the market. He would, therefore, probably have been skeptical of the policy implications of the new trade theory, even though he might have agreed on how the theory analyzes the foundations behind a large part of the present trade.

What about his view on the multinational firm as a phenomenon? Or expressed differently, what kind of theory of the multinational firm is most in line with his reasoning in" An Inquiry into the Nature and Causes of Wealth of Nations"? This is of course impossible to say. The multinational firm in its present form did not exist at that time. But we know two things: he disliked monopolies and he was very concerned when it comes to economic power. Adam Smith was as acutely aware of issues of power and class as he was of the dynamics of competitive markets (Korten 2001). In that sense, the political economy of Adam Smith was a much broader, more humane subject than the mainstream neoclassical school of economics. The latter theory was left out of most of his political and institutional analyses. Especially, the concept of class has simply been banned (Nolan 2003).

In that sense, his concern with structural imperfections rather than natural imperfections would have led him to address Hymer's market power analysis more than the transaction cost economics model of the multinational firm. Firm-specific advantages based on market concentration, barriers of entry, market collusion, concessions from governments, etc. would probably have been his major concern rather than the internalization advantage as a base for multi-nationality. From this, it follows that Adam Smith would probably have had some difficulties in accepting the implicit view in the Transaction Cost Economics (TCE) explanation that multinational firms exist because they are the most efficient institutions to handle transaction costs. The aggregation of economic resources in the multinational firms and the economic and political power concentrated at the top of such organizations of today would probably have been his main concern. And he would probably have repeatedly mentioned the difficulties of arranging for the invisible hand to do its theoretical best (Koenig and Waters 2002).

From this, it follows that he would probably have found good reasons to apply the institutionalization theory as a tool for analyzing the multinational firm. This theory opens up for a different and broader analysis of these organizations than the traditional view, especially concerning the firms as political actors (Forsgren 2008). He would have recognized that many firms have considerable power to shape their political environment 
in line with their own interests. After all, he pointed out that businessmen are "an order of men, whose interest is never exactly the same with that of the public, who have generally an interest to deceive and even to oppress the public, and who accordingly have, upon many occasions, both deceived and oppressed it" (Smith 1776, p. 267). He would also probably have been highly interested in corporate social responsibility (CSR) issues and the question about whether CSR is something that can contribute to the delicate balance between profits and public interests. Contrary to the mainstream neoclassical analysis of the multinational firm, he would address these issues in depth. After all, the moral dimension of business life is a serious matter in Adam Smith's writings.

\section{Adam Smith and The `Moral’ Limits to Globalization}

As we have seen, Adam Smith is widely regarded as the original intellectual inspiration of free-market economics. To the extent that 'globalization' can be characterized as a process whereby cross-border markets increasingly govern international trade and investment flows, it may be supposed that Adam Smith would have championed or at least broadly approved of globalization. Yet, a strong argument can be made for the opposite case: Adam Smith would not necessarily wholeheartedly support the advocacy of free markets enthusiastically undertaken by the Adam Smith Institute. The 'Smithian' argument against globalization entails a recognition that Adam Smith was more of a moral or ethical theorist than a 'pure' economist (McClosky 2008), and, as such, believed that the effective operation of the market economy always presupposes a normative/moral consensus. Although he did not develop this view fully, there is nevertheless ample indication in his book "The Theory of Moral Sentiments" that he would have endorsed what came to be known, through the work of Karl Polanyi (1957), as the 'double movement' - that is to say the movement towards the market economy on the one hand and towards the socially protective institutions to safeguard the community against market contingencies on the other (Day 2005). From this perspective, the central idea in "The Theory of Moral Sentiments" implies limits to globalization due to the inherent difficulties of developing overarching global institutional and political authority that would legitimize globalization.

It is interesting that in the current international business literature there is a forceful rejection of the relevance of globalization as the strategy of most multinational enterprises (Rugman 2005). Due to the persistent and extensive diversities in culture, institutions, values, and economic systems, there are deeply rooted differences in the 'rules of engagement' between 
(the triad) regions. Accordingly, most multinationals in fact adopt a home region strategy. In a similar vein, characterizing SME internationalization as 'born global' is misleading. It may be the case that speed of internationalization has increased and SMEs can venture beyond their national boundaries soon after their 'birth' - sooner probably than predicted by the traditional Uppsala model (Johansen and Vahlne 1977; Forsgren 2002). However, it is not necessarily the case that SMEs can have a 'global' scope or venture very far from their home base. Furthermore, rapid SME internationalization may well be dependent on pre-existing cross-border relational networks (Sharma and Blomstermo 2003). Also, while Information Communications Technology (ICT) advances and the internet can facilitate rapid internationalization, it is also the case that 'online' internationalization may be vulnerable to a 'virtuality trap' (Yamin and Sinkovics 2006). In sum, it is still the case that physical proximity, relational networks, and local knowledge matter greatly in cross-border business. Our reading of Adam Smith suggests to us that he would share this view and would be dismissive of the hype around the supposed 'death' of distance.

However, in terms of a deeper sense of popular identity and thus legitimate political and institutional governance, even the (triad) regions may be too large. For example, few Europeans would probably regard European Union (EU) political institutions as 'really' theirs or owe greater allegiance to these institutions than to their country or local political systems (Day 2005). The tensions around the possibility of Turkey's accession to the EU illustrate the limits of regional solidarity, as does the reservation in Germany to support Greece's bailout.

In the "Theory of Moral Sentiments," Adam Smith develops a theory of individual moral responsibility. He sees human beings as fundamentally disposed to 'sympathy' and 'fellow-feeling': "How selfish so ever man maybe supposed there are evidently some principles in his nature which interest him in the fortune of others" (Smith 2006, p. 3). However, the apparent 'natural' capacity for sympathy is in fact a product of social interaction and experience. Thus, according to Adam Smith, the general rules of morality are 'ultimately founded upon the experience of what, in particular instances, our moral faculties...approve or disapprove of' (op . cit, p.153). But the latter, in turn, emerges from our 'continual observation upon the conduct of others [which] insensibly lead us to form to ourselves certain general rules concerning what is fit and proper either to be done or avoided' (op.cit, p. 153). Thus, expressed in somewhat more modern parlance, Adam Smith, in effect, stresses that these 'general rules' are socially embedded and that 'sympathy' operates mostly at close quarters. In particular, they are not very strong at a trans-national or global level. 
Thus, he points out that the love of our own country seems not to be derived from the love of mankind. "That wisdom which contrived the system of human affections...seems to have judged that the interest of the great society of mankind would be best promoted by directing the principal attention of each individual to that particular portion of it, which was most within the sphere both of his abilities and of his understanding." (op.cit, p. 231).

Thus, from a moral perspective, markets have a contradictory effect: they bring us into contact with ever more distant peoples but at the same time they weaken social bonds of sympathy and fellow-feelings. And, what is more to the point, markets do not by themselves create new bonds of sympathy and fellow-feelings.

Adam Smith argues that while the success of people at the 'middling stations of life' (small, local business?) almost always depend on the good opinion of their neighbors and equals (which) 'without a tolerably regular conduct can seldom be obtained, making the good proverb that honesty is the best policy holds, in such situation, almost always perfectly true,' this is not necessarily the case at the 'superior stations of life' (Smith 2006, p. 59-60). The division of labor creates conditions in which the virtue of prudence tends to grow (become corrupted) into the vices of vanity and avarice. Adam Smith expresses the contradiction of market society in terms of fundamental 'deception.' In the chapter on the 'Origins of Ambition,' he elaborates on the 'deception' that wealth brings happiness: 'to what purpose is all the toil and bustle of this world? What is the end of avarice and ambition, of the pursuit of wealth, of power and of pre-eminence? Is it to supply the necessities of nature? The wages of the meanest labourer can supply them...it is the vanity not the ease or the pleasure that interests us. But vanity is always founded upon the belief of our being the object of attention and approbation. The rich man glories in his riches because he feels that they naturally draw upon him the attention of the world' (Smith 2006, p. 48).

Unfortunately(!), this deception is necessary for the development of capitalism; wealth is desired because greatness is admired and admiration is one of the most powerful incentives for productive activity. If we were concerned only with immediate needs, there would be no accumulation and thus no economic progress. But this incentive is also morally corrupting. Adam Smith is very explicit on this:

'The disposition to admire ... the rich and powerful and to despise or neglect persons of poor and mean condition, though necessary both to 
establish and to maintain the distinctions of rank and order of society is, at the same time, the great and universal cause of the corruption of our moral sentiments' (op.cit, p. 58).

In "An Inquiry into the Nature and Causes of Wealth of Nations," Adam Smith pinpoints a manifestation of this moral corruption in terms of the wealthseeking behavior of capitalists and regards them as potential conspirators against the public for the simple reason that monopoly increases profit. Looked at in another way, the corruption of moral sentiments arise because prudence' is a much stronger sentiment than beneficence. 'Prudence' is what we would now call 'self' interest; beneficence is a soft power of humanity and only a relatively 'feeble spark' that grows weaker as the relationships become more remote. An earthquake could swallow the 'great Empire of China' but mean less to a European than the loss of his little finger. Beneficence may be a fairly strong affection in pastoral societies, but in commercial societies the regard for remote relations becomes less and less. To put the issue in a modern context, we may buy shoes made by child labor in distant lands because we have no immediate experience of the suffering.

However, since prudence is so powerful as to displace beneficence and even tends to grow over into avarice and indifference to the suffering of others, Adam Smith brings a third virtue to establish 'balance' - this virtue is justice. Justice for him has both an internal and external dimension. So far as the external dimension of justice is concerned, Adam Smith stresses 'fairness': 'In the race for wealth and honors and preferment each may run as hard as he can and strain every nerve and muscle in order to outstrip his competitors. But if he should jostle or throw down any of them, the indulgence of the spectator is at an end. It is violation of fair play which they cannot admit of' (Smith 2006, p. 83).

Thus, rules of justice (especially externally enforced justice) tie the loose ends for Adam Smith. Avarice is or can be externally regulated and thus constrained. For him, justice is the indispensible condition of social stability. Without it, 'men are like wild beasts.'

\section{SUMMARY}

We have argued that the concept of "the invisible hand" plays a less profound role in Adam Smith's thinking than is usually assumed in mainstream economics. In "An Inquiry into the Nature and Causes of Wealth of Nations," it is used in connection to a strong plea for a policy of removing trade barriers and other governmental subsidies to specific industries or 
firms. It is applied more or less as an ironic observation of human behavior rather than as a plea for a social system with as limited rules and regulations as possible. He wanted to persuade all those in favor of different kinds of subsidies to different industries and firms that if those subsidies are removed, the firms will do their best and earn money anyway. His main concern was unfair regulations, which supported some actors at the cost of others, not regulations as such. In"An Inquiry into the Nature and Causes of Wealth of Nations," there is ample evidence that he wanted to create an order of the market in which the possibility for some business actors to use their political and market power to get beneficial treatments by the Crown would be eliminated. Such an order would not be achieved with as few regulations as possible but with right and fair regulations. It is also interesting to observe that although he was much in favor of free trade, he thought that it should not be based on nations' self-interest but on sympathy and friendship. He was concerned by the fact that so much international trade had "become the most fertile source of discord and animosity." In that sense, Adam Smith's concern about international trade contains a warning against the invisible hand rather than only a plea for it.

The interpretation and application of the invisible hand after Adam Smith is probably highly connected to letting the term "political economy" fall into disuse, especially when Alfred Marshall coined the term "principles of economics" (Marshall 1920). Economics became more technical than political and the invisible hand metaphor became an important element in reducing politics to a more marginal role in economic theory (Strange 1988).

His view in "An Inquiry into the Nature and Causes of Wealth of Nations" on the firm as a business actor has some important bearings on the multinational firm of today. First of all, he disliked joint-stock, limited-liability companies, controlled by managers rather than owners. He distrusted people controlling other people's money. His vision of the business actor was the (small) firm in which the owner also manages the operations and immediately experiences the costs and benefits of his own management. Although he was much in favor of firms taking part in international trade, Adam Smith's firm was basically a domestic firm in the sense that the firm will first of all invest its capital at home, not abroad. He did not believe in the "foot-loose" character of the firm. This also plays an important role in his argument that no special support of the domestic industry, e.g., in terms of imports restrictions, is needed. In many ways, therefore, his view on what a"good" company is from a societal point of view deviates considerably from the features of the contemporary multinational corporation. A fair guess is that he would have been particularly concerned with 
the market and political power of these firms. He disliked all kinds of monopolies and beneficial treatments that some actors can get from the government through political pressures. He also had a long-term perspective on business. He preferred conservative business practices and disliked speculation and short-term, risk-oriented business behavior. Also in that sense, he would probably have been extremely concerned with a lot of what we see today, especially among multinational firms.

For Adam Smith, economic life is also a question of morals, especially articulated in "The Theory of Moral Sentiments." Economic life always contains a battle between prudence and beneficence. There is a constant risk that prudence will take over and turn into moral corruption, for instance by using political and market power to get above-normal profits. For Adam Smith this is a basic element in capitalism. On the one hand, striving for richness and admiration is necessary for capital accumulation. On the other hand, it is a universal cause of the corruption of our moral sentiments. The risk of moral corruption is counter-balanced by the fact that all business is carried out in a social context, that is, beneficence is socially embedded. Moral corruption is therefore limited to the extent that other but close actors (friends, neighbors, trade partners, etc.) evaluate and judge the actor's moral behavior. But Adam Smith argues that justice, not least-enforced justice, is also needed in order to hinder prudence from turning into moral corruption. Socially embedded beneficence alone is not enough. This reasoning seems to be in line with Karl Polanyi's"double movement" - movement towards a market society requires a movement towards a system of socially protective institutions to safeguard the community against market contingencies. This reasoning also implies a limit to globalization due to the inherent difficulties of developing overarching global institutions that could legitimize globalization.

Adam Smith's reasoning implies that the risk of moral corruption increases with geographic distance due to beneficence being socially embedded. This will create problems for how globalization can be combined with morally justified business.

To summarize, based on our reading of Adam Smith's work, we argue that he would not have been a comfortable member of the Adam Smith Institute. Maybe he would have refrained from being a member at all! 


\section{REFERENCES}

Day, R. 2005. Globalization, markets and ethics. Perspectives on Global Development and Technology. 4(2): 251-303.

Fligsten, N. 2001. The Architecture of Markets: An Economic Sociology of Twenty-First-Century Capitalist Societies. Princeton, NJ: Princeton University Press.

Forsgren, M. 2002. The concept of learning in the Uppsala internationalization process model: A critical review. International Business Review. 11(3): 257-277.

Forsgren, M. 2008. Theories of the Multinational Firm. A Multidimensional Creature in the Global Economy. Cheltenham: Edward Elgar.

Johanson, J., and J.-E.Vahlne. 1977. The internationalization process of the firm - a model of knowledge development and increasing foreign market commitments. Journal of International Business Studies. 8(1): 23-32.

Koenig, Ph. C, and R.C. Waters. 2002. Adam Smith on management. Business and Society Review. 107(2), 241-253.

Korten, D.C. 2001. When Corporations Rule the World. Bloomfield CT: Kumarian Press.

Marshall, A. 1920. Principles of Economics. London: McMillan.

McCloskey, D. 2008. Adam Smith, the last of the former virtue ethicists. History of Political Economy. 40(1): 43-71.

Myint, H. 1971. Economic Theory and Underdeveloped Countries. Oxford: Oxford University Press.

Nolan, P. 2003. Adam Smith and the contradictions of the free market. Challenge. 46(3): 112-123.

Polanyi, K. 1957. The Great Transformation: The Political and Economic Origins of Our Time. Boston: Beacon.

Rodrik, D. 1997. Has globalization gone too far? Institute for International Economics: Washington, DC.

Rothschild, E. 1994. Adam Smith and the invisible hand. American Economic Review. Vol. 84(2): 319-323.

Rugman, A. 2005. The Regional Multinationals: MNEs and 'Global' Strategic Management. Cambridge: Cambridge University Press.

Sharma, D.D., and A. Blomstermo. 2003. The internationalization process of born globals: A network view. International Business Review. 12(6):739-753. 
Sen, A. 2009. Capitalism beyond the crisis. The New York Review of Books. 56(5): 1-7.

Smith, A. 1776. An Inquiry into the Nature and Causes of Wealth of Nations. Oxford: Oxford University Press (originally published 1776).

Smith, A. 2006. The Theory of Moral Sentiments. Dover Philosophical Classics. New York: Diver Publications (originally published in 1759).

Strange, S. 1988. States and Markets. London: Pinter Publishers.

Strange, S. 1996. The Retreat of the State. Cambridge: Cambridge University Press.

Yamin, M., and R.R. Sinkovics. 2006. Online internationalization, psychic distance reduction and the virtuality trap. International Business Review. 15(4): 339-360. 
